UDC 37.013.78

DOI: 10.15587/2519-4984.2021.241186

\title{
GLOBAL IMPERATIVES OF ECONOMIC COMPONENT DEVELOPMENT OF GENERAL SECONDARY EDUCATION IN UKRAINE
}

\section{Iryna Klymchuk}

A literary analysis of economic issues of financing education by the state, in accordance with international law and globalization of the world economy in order to implement the right to quality education is presented. A conceptual analysis of the system of improving the financing of educational institutions in Ukraine, in particular the specifics and various mechanisms for raising funds and international cooperation of developing countries with developed countries and international programs has been conducted. In addition, the results of international assistance to Ukraine, including financial assistance at the level of general education - international charitable assistance in the form of an international project "House of Europe", within the international programs "Erasmus + " and "European Solidarity Corps" are analyzed. The international program "House of Europe" is presented, which supports creative cooperation between Ukrainian organizations, educational institutions and their partners from the EU and the UK, finances the development of cultural infrastructure and educational programs for young people. Also presented is the Erasmus + Program (2021-2027), an EU program to support and develop education, training, youth and sport in Europe. The program focuses on the social integration of young people, the environmental and digital development of developing countries, and the participation of young people in democratic life.

According to the results of joint activities within the international program / project "House of Europe", the international program "Erasmus" and the European Solidarity Corps, the most defined criteria for the quality of general secondary education are identified, namely: objective assessments of educational institutions - student performance tests, the probability of successful entry into prestigious colleges and universities after graduating from primary and secondary school; as well as subjective assessments - attendance of classes, received assessments (success), students' interest in certain training courses / programs, taught in an educational institution.

Statistics on the activities of the "ESC Summary" / European Solidarity Corps and "Erasmus + " for 2019-2020 according to the reporting "ESC Summary" / European Solidarity Corps and "Erasmus + " are presented

Keywords: international financial cooperation of countries, international program "House of Europe", international program "Erasmus", "Summary ESC" / European Solidarity Corps and "Erasmus +"

\section{How to cite:}

Klymchuk, I. (2021). Global imperatives of economic component development of general secondary education in Ukraine. ScienceRise: Pedagogical Education, 5 (44), 11-14. doi: http://doi.org/10.15587/2519-4984.2021.241186

(C) The Author(s) 2021

This is an open access article under the Creative Commons CC BY license hydrate

\section{Introduction}

Globalization is an objective and comprehensive process that is characteristic of the modern development of the world economy. It is impossible to stop the progressive unification process, aimed at involving Ukraine in the integration process, and this causes various and ambiguous consequences for the national economy, which affect education, science and culture of the country. The positive or negative vector of these consequences largely depends on the level of development of the national economy, the country's position in the world rankings. In the conditions of deepening of the process of financial globalization and strengthening of its influence on the development of national economies, such state policy, which stimulates effective development of national financial systems and promotes their influence on science, education, culture, becomes important. The exceptional relevance of the study of problems and features of the impact of globalization on the development of education in Ukraine is also relevant in terms of developing a comprehensive system of its measurement in order to predict their consequences and effective management of educational processes

\section{Literary review}

The realization of the right to education presupposes sufficient financing of education by the state, which, in accordance with international law, is obliged to use the maximum of its available resources in order to exercise this right. This provision is enshrined in Article 78 of the Law of Ukraine "On Education", which states that the state provides allocations for education in the amount of not less than $7 \%$ of gross domestic product from state, local budgets and other sources of funding, not prohibited by law. According to the Budget Code of Ukraine and the Laws of Ukraine "On Education", "On Complete General Secondary Education" [1, 2], financing of state and municipal institutions of general secondary education is carried out at the expense of state, local budgets and other sources, not prohibited by law ( charitable assistance, in the form of funds, grants).

Institutions of general secondary education receive an educational subvention from the state budget for the remuneration of educators with accruals to teachers in terms of ensuring the costs of obtaining complete general secondary education. Subventions for support of the New Ukrainian School, organization of inclusive education, subvention "Able school for better results" for support of basic schools 
(repairs, purchase of equipment, school buses, etc.) are also allocated from the state budget for general secondary education institutions [3]. Studies of domestic and foreign scientists are devoted to financial issues, problems of finding and attracting additional funding for general secondary education institutions in Ukraine $[4,5]$. The problems of globalization of the economy and the interaction of developed countries with developing ones are dealt with by the National Council for Economic Education of the United States in Ukraine - American Academic Exchange Programs (International Project) [6]. In addition, the analysis of problems of development of financial systems of developing countries in terms of features and contradictions of modern globalization processes is conducted by experts of the UNIAN News Agency [7], the European Central Bank for Reconstruction and Development of Southern and Eastern Europe (BGCEE) [8], relevant statistical and scientific publications $[9,10]$ are developed and funded by international funding programs for developing countries - the International House of Europe Program [11] and the Erasmus + International Program [12]; foreign financial experts [13, 14]. Unfortunately, there is no clear mechanism for the interaction of state and international financial assistance to general secondary education institutions in Ukraine.

\section{Research aim and tasks}

The aim of the study is to identify the patterns of financial globalization, theoretical justification of its impact on the national education system, in particular the study of the impact of international financial assistance on the development of general secondary education in Ukraine.

To achieve this goal, the following tasks were set:

1. Study of the impact of international financial assistance on the development of domestic general secondary education in Ukraine.

2. Study of the interaction of international charitable assistance in the framework of international programs "House of Europe", "Erasmus +" and "European Solidarity Corps" with the system of domestic general secondary education in Ukraine.

\section{Materials and methods}

Research materials: Laws of Ukraine: "On Education" [1], "On Complete General Secondary Education" [2]; "Concept of a new Ukrainian school" [3], American programs of academic exchanges [6], UNIAN News Agency [7], International program "House of Europe" [11]; International program "Erasmus +" [12]; Altbach, P.G., and Knight, J. (2007). The Internationalization of Higher Education: Motivations and Realities. J. Stud. Int. Educ. 11, P.290-305 [13]; Amaral, A., Neave, G., Musselin, C., and Maassen, P. (2009). European integration and the governance of higher education and research. Higher Educ. Dynam., Vol. 6, p.11 [14]; Elken, M., Gornitzka, A, Maassen, P., and Vukasovic, M. (2011). European integration and the transformation of higher education. University of Oslo research paper, p. 57 [15]; Janmaat, J.G. (2008). Nation-Building, Democratization and Internationalization as Competing Priorities in Ukraine's Education System. Nation. Papers. Vol. 36, P. 1-23 [16].

The methodological basis is general scientific methods of comparison and generalization, methods of systematic, comparative, structural and functional analysis - to search and analyze the information about the purpose, subject and objectives of the study, methods of economic analysis - to find and structure relevant information.

\section{Research results}

The conducted theoretical analysis of the global imperative-economic component of the development of general secondary education in Ukraine provides an opportunity to generalize the process of internationalization of finances and their impact on the development of education in Ukraine. It was found, that it is advisable to identify areas of internationalization of finances (banking, investment, education, etc.), its levels (assistance/grants at the micro and macro levels), types (internal and external assistance), types (natural and forced), ways, depending on the development of the country (interval, extreme) $[10,13,14]$.

On the basis of thorough research of the evolution of the idea of cyclical global development of the world, analysis of historical experience, the current state of development of the world economy and finance, the hypothesis of accelerating or slowing down the intensity of economic globalization is substantiated. Yes, globalization is a constant and inevitable process. But depending on many factors of the country's development (political, economic, information technology, environmental), the intensity of its development may accelerate or, conversely, slow down. Accordingly, international assistance, provided in Ukraine, may cover different levels of opportunities and prospects for further development of all participants in international programs/projects. Examples of international financial assistance at the level of general education in Ukraine are: American academic exchange programs [6], international charitable assistance House of Europe ", in the framework of international programs" Erasmus + "and" European Solidarity Corps "[11, 12].

House of Europe is an international program, funded by the European Union, designed to support professional and creative exchanges between Ukrainians and their counterparts in the EU and the UK. The program focuses on education, culture, medicine, social entrepreneurship, media and youth work and provides more than 20 educational programs: conferences, seminars, internships and networking in the EU and the UK, educational programs, summer language camps, travel, training and other opportunities for young people. The House of Europe team supports creative cooperation between Ukrainian organizations, educational institutions and their partners from the EU and the UK, and funds the development of the cultural infrastructure and educational programs for young people (summer youth camps and student exchanges between Ukrainian and EU universities). The subject of the program provides for advanced training and is represented by the following areas: best practices of educational management and development of management skills; acquaintance with professional cultures of the EU and Great Britain; practices and principles of learning in the EU and the UK; "Inclusion in learning"; "New Ukrainian School" and competence approach to learning; "Learning foreign languages and multilingual education". Online training under the House of Europe program also provides grants for these programs [11].

The Erasmus + program (2021-2027) is a EU program to support and develop education, training, 
youth and sport in Europe. The estimated budget of the program is 26.2 billion euro. This is almost twice as much funding as the previous program (2014-2020). The program focuses on the social integration of young people, the environmental and digital development of developing countries, and the participation of young people in democratic life. Erasmus + offers opportunities for mobility and cooperation in higher, vocational and secondary education, adult education and sports. The program gives millions of young people, including citizens of developing countries, greater opportunities for selfdevelopment, ensuring the quality of education and improving the prospects for individual development of all participants. According to the report for 2019, thousands of students, including pedagogical universities, pupils, teachers, have undergone training and internships abroad. In the budget for the period 2019-2020, with a total amount of 3.37 billion euro, Erasmus + launched 940,000 educational programs correspondingly for heads of educational institutions. The program funded more than 111,500 educational institutions and 25,500 educational projects.

According to the "Summary ESC" of the European Solidarity Corps (as part of the House of Europe program), there has been "Unprecedented involvement of all interested in order to enable young people aged 18 to 30 to be actively involved in public life and develop new skills, ensure personal development and opportunities for further employment" [12]. According to statistics for 2019-2020, more than $83 \%$ participants who took part in the activities of the European Solidarity Corps emphasized that the knowledge and skills, acquired in the process of participation, will be useful in their future studies and future careers. The European Solidarity Corps also assists non-profit organizations, including educational institutions, in addressing educational issues - "in a wide range of geographical areas." According to the report for the period of 2019, almost a quarter of a million young people from Ukraine were registered in the European Solidarity Corps, which contributed to the implementation of "solidarity measures", ranging from various international educational programs to educational activities in the fight against climate change.

In total, in 2019-2020, according to the "Summary ESC" of the European Solidarity Corps and Erasmus + Summary, more than 273,000 young people were given the opportunity to participate in international projects/programs, funded by international organizations. In Ukraine, about 2,300 organizations, including more than 1,000 secondary schools, submitted their proposals for participation in joint projects, aimed at solving existing educational and social problems at the local, regional, national and international levels. The total amount of project support for 2019-2020 amounted to more than 113.5 million euro [11, 12].

\section{Research results discussion}

One of the most important areas of research in the economics of education - studies of criteria for the quality of educational services, provided by educational institutions (in Western literature it is called "study of production functions of education", "analysis of production functions of education"). According to the results of joint activities within the framework of the international program/project
"House of Europe", the international program "Erasmus" and the European Solidarity Corps, among the most frequently mentioned criteria for the quality of general secondary education in Ukraine are, first of all, objective evaluations of students according to the results of standardized tests, the probability of successful entry into prestigious colleges and universities after graduating from primary and secondary school; as well as subjective assessments, namely: attendance, grades (success), students' interest in certain training courses/programs, taught in an educational institution, etc. The results are obtained on the basis of a sociological survey in different periods of the educational process, in different age categories of students and in different educational institutions in accordance with their profile. If the study is about the quality of secondary education and its final results in terms of financial component, it is possible to consider options for further education and careers of school graduates depending on the financial security/competitiveness of relevant secondary education institutions. As for the determinant qualities of educational services, provided in educational institutions, they are usually influenced by both indicators of material and technical base/provision of educational institutions and "human factor/capital - teachers, heads of educational institutions their material incentives and financial support / opportunities of different contingents of students (for example, financial opportunities of their families) [13, 14].

According to the results of the joint report on Western Europe and the United States, considerable attention is also paid to the issue of comparing public and private educational institutions, studying the quality of educational services depending on the ratio of different sources of funding. The result is a rating of the levels of education indicators ("knowledge formation") of the country in the"Global Innovation Rating 2020", according to which Ukraine is ranked 39-th in terms of education.

The impact of globalization processes can lead to unpredictable and possibly catastrophic consequences for the development of society in any country in the world. In such conditions, it is the national interests of forming a stable, effectively functioning educational system in Ukraine at all its levels that should come to the fore. In Ukraine, it is more appropriate to develop a "mixed" model of financing and development of general secondary education, which meets the requirements of the existing reality, financial capabilities of the country and has a forecast for the future, namely: ensuring equal access to general secondary education for all children. The limited implementation of other models of education financing is related to the need to attract different mechanisms and different sources of funding, develop a technology for non-governmental funding of educational institutions, increase financial independence of educational institutions, stimulate competitiveness of institutions and limited state control over secondary education. There is also a need to develop practical recommendations for the development of the Ukraine's education financing system with a forecast for the future.

\section{Conclusions}

1. The study of the impact of international financial assistance on the development of domestic general secondary education in Ukraine allowed to determine the nature and trends of globalization on the development of 
domestic general secondary education at the current stage of development, to analyze the methodological foundations of international financial assistance in education, to determine probable positive and negative consequences of globalization, to test the hypothesis of accelerating or slowing down the intensity of development of domestic general education depending on the degree of interaction with international financial assistance.

2. The study of international financial assistance at the level of general education in Ukraine, represented by international charitable assistance in the form of the international program/project "House of Europe", the international program "Erasmus" and the European Solidarity Corps, confirmed the hypothesis of the need to attract international financial assistance to Ukraine in order to bring the level of domestic general education to international standards due to the international globalization of the world economy. The probable positive and negative consequences of financial globalization for the education sector are summarized. Among the negative: the outflow of public financial resources from the real sector of education, increasing the uneven distribution of international financial resources between countries depending on the development opportunities of the country, political and economic instability. The positive consequences are: modernization of the entire educational system in Ukraine, the emergence of new financial and educational tools to find and attract additional sources in general secondary education, the introduction of innovations, information technology, international educational courses/programs.

3. The study of the essence of the impact of globalization on education in Ukraine was conducted taking into account the impact of this process on individual subjects of educational activity, namely general secondary education institutions. It should be noted, that on the one hand, globalization has a positive impact on the development of education in Ukraine, opens opportunities for the use of a number of tools to find and attract additional opportunities for general secondary education, while globalization creates financial dependence and necessitates additional mechanisms, taking into account the level and economic opportunities of the country itself.

\section{References}

1. Pro osvitu (2017). Zakon Ukrainy No. 2145-VIII. 05.09.2017. Available at: https://zakon.rada.gov.ua/laws/show/2145-19\#Text

2. Pro povnu zahalnu seredniu osvitu (2020). Zakon Ukrainy No. 463-IX. 16.01.2020. Available at: https://zakon.rada.gov.ua/laws/ show/463-20\#Text

3. Kontseptsiia novoi ukrainskoi shkoly. Available at: https://www.pedrada.com.ua/article/2372-ad-fontes-pro-kontseptsyunovo-ukransko-shkoli

4. Arkhirieiev, S. I. (Ed.) (2018). Global economy. Kharkiv: Vydavnytstvo Ivanchenka I. S., 192. Available at: http://dspace.ksau.kherson.ua/bitstream/handle/123456789/4647/\%20\%20\%20\%20\%20\%20\%20\%20\%20\%20\%20\%20\%20\%20\%20\% $20 \% 20 \% 20 \% 20$.pdf?sequence $=1$

5. Lukianenko, D. H., Poruchnyk, A. M., Kolot, A. M., Stoliarchuk, Ya. M. et. al.; Lukianenko, D. H., Poruchnyk, A. M. (Eds.) (2011). Resursy ta modeli hlobalnoho ekonomichnoho rozvytku. Kyiv: KNEU, 703. Available at: https://kneu.edu.ua/ua/science_kneu/ scientific_schools/ustv/ustv_praci/ustv_prazi/rtmger/

6. Amerykanski prohramy akademichnykh obminiv. Available at: https://www.donnu.edu.ua/uk/osvitni-mozhlivosti-yakinadaye-posolstvo-ssha-v-ukrayini/

7. Ukraina pidnialasia na 17 pozytsii u reitynhu autsorsynhovoi pryvablyvosti, zainiavshy 24-te mistse (2016). Informatsiine ahenstvo UNIAN. Available at: https://www.unian.ua/science/1237760-ukrajina-pidnyalasya-na-17-pozitsiy-u-reytingu-autsorsingovojiprivablivosti-zaynyavshi-24-te-mistse.html

8. Yevropeiskyi tsentralnyi bank rekonstruktsii ta rozvytku. Available at: https://uk.wikipedia.org/wiki/\%D0\%84\%D0\%B2\% D1\%80\%D0\%BE\%D0\%BF\%D0\%B5\%D0\%B9\%D1\%81\%D1\%8C\%D0\%BA\%D0\%B8\%D0\%B9\%D0\%B1\%D0\%B0\%D0\%BD\%D0 \%BA_\%D1\%80\%D0\%B5\%D0\%BA\%D0\%BE\%D0\%BD\%D1\%81\%D1\%82\%D1\%80\%D1\%83\%D0\%BA\%D1\%86\%D1\%96\%D1\%97_ $\% \mathrm{D} 1 \% 82 \% \mathrm{D} 0 \% \mathrm{~B} 0 \% \mathrm{D} 1 \% 80 \% \mathrm{D} 0 \% \mathrm{BE} \% \mathrm{D} 0 \% \mathrm{~B} 7 \% \mathrm{D} 0 \% \mathrm{~B} 2 \% \mathrm{D} 0 \% \mathrm{~B} 8 \% \mathrm{D} 1 \% 82 \% \mathrm{D} 0 \% \mathrm{BA} \% \mathrm{D} 1 \% 83$

9. Ukraina - Learning Nation. Available at: https://strategy.uifuture.org/ukraina-learning-nation.html

10. Klymchuk, I. O. (2014). Teoriia i tekhnolohii realizatsii investytsiinykh mekhanizmiv u shkilnii osviti. Kyiv, 87. Available at: http://lib.iitta.gov.ua/707330/1/KLimchuk_posibnik_2014r_KLMISBN.pdf

11. Mizhnarodna prohrama «House of Europe». Available at: https://npu.edu.ua/universytet/mizhnarodne-spivrobitnytstvo/ mizhnarodni-hranty-ta-stypendii/house-of-europe-dim-yevropy

12. Mizhnarodna prohrama «Erasmus+». Available at: https://ec.europa.eu/programmes/erasmus-plus/about_en

13. Altbach, P. G., Knight, J. (2007). The Internationalization of Higher Education: Motivations and Realities. Journal of Studies in International Education, 11 (3-4), 290-305. doi: http://doi.org/10.1177/1028315307303542

14. Amaral, A., Neave, G., Musselin, C., Maassen, P. (2009). European integration and the governance of higher education and research. Higher Education Dynamics, 6, 11. doi: http://doi.org/10.1007/978-1-4020-9505-4

15. Elken, M., Gornitzka, A, Maassen, P., Vukasovic, M. (2011). European integration and the transformation of higher education. University of Oslo research paper, 57. Available at: https://www.academia.edu/17496953/European_integration_and_the_ transformation_of_higher_education

16. Janmaat, J. G. (2008). Nation-Building, Democratization and Internationalization as Competing Priorities in Ukraine's Education System. Nationalities Papers, 36, 1-23. doi: http://doi.org/10.1080/00905990701848317

Received date 17.08.2021

Accepted date 21.09.2021

Published date 30.09.2021

Iryna Klymchuk, PhD, Senior Researcher, Department of Innovation and Education Development Strategy, Institute of Pedagogy of the National Academy of Pedagogical Sciences of Ukraine, Sichovykh Striltsiv str., 52-D, Kyiv, Ukraine, 04053

E-mail: Klimchuk.irina@gmail.com 